REVIEW ARTICLE

\title{
The Capsalidae (Monogenea: Monopisthocotylea): a review of diversity, classification and phylogeny with a note about species complexes
}

\author{
Ian D. Whittington ${ }^{1,2}$ \\ ${ }^{1}$ Monogenean Research Laboratory, Parasitology Section, The South Australian Museum, North Terrace, Adelaide, South \\ Australia 5000, Australia; \\ ${ }^{2}$ Marine Parasitology Laboratory, School of Earth and Environmental Sciences, The University of Adelaide, North Terrace, \\ Adelaide, South Australia 5005, Australia
}

Key words: Platyhelminthes, Monogenea, Capsalidae, Entobdellinae, Entobdella, Benedeniinae, Neobenedenia melleni, subfamilies, systematics, morphology

\begin{abstract}
The Capsalidae are monogeneans parasitizing 'skin', fins and gills of marine fishes. Some capsalids are pathogenic to cultivated fish and a few have caused epizootic events. It is a cosmopolitan family with broad host associations (elasmobranchs and teleosts, including sturgeons). Approximately 200 capsalid species are placed in nine subfamilies and 44-46 genera, some of which are well known (Benedenia, Capsala, Entobdella, Neobenedenia). Sturgeons host two capsalid species (Nitzschiinae) and 15 species in five genera are reliably reported from elasmobranchs. The combination of ancient (shark, ray, sturgeon) and modern (teleost) host fish lineages indicates that capsalid evolution is likely a blend of coevolution and host-switching, but a family phylogeny has been lacking due to deficient knowledge about homologies. The current phenetic subfamilial classification is discussed in detail using a preliminary phylogeny generated from large subunit ribosomal DNA sequence data from representatives of five subfamilies. Monophyly of the Capsalidae is supported by possession of accessory sclerites. Hypotheses are proposed for the possible radiation of capsalids. A suggestion that Neobenedenia melleni, a pathogenic species atypical due to its broad host-specificity ( $>100$ host teleost species from $>30$ families in five orders), may be a complex of species is supported from genetic evidence. This may explain peculiarities in biology, taxonomy, host associations and geographic distribution of $N$. 'melleni' and has implications for fish health. Holistic studies using live and preserved larval and adult capsalid specimens and material for genetic analysis are emphasised to further determine identity, phylogeny and details of biology, especially for pathogenic species.
\end{abstract}

The Monogenea is a class of platyhelminths parasitic mostly on external surfaces and gills of freshwater and marine fishes. Boeger and Kritsky (2001) recognised 53 families in the most recent phylogenetic analysis of the class based on morphological characters, but omitted at least ten other 'families' because of uncertainties about origins and/or validity. Although the Capsalidae (Monopisthocotylea, or the Polyonchoinea of Boeger and Kritsky 2001) is included in the analysis of Boeger and Kritsky (2001), Kritsky and Fennessy (1999) commented that confirmation of the monophyly of subfamilies comprising the family was lacking. Boeger and Kritsky (2001) highlighted further contention about capsalid composition by indicating that some microbothriid species (monogeneans that characteristically cement their haptor to denticles of sharks and batoids; e.g. see Whittington and Chisholm 2003) might, in fact, be capsalids. In addition to the validity and phylogenetic position of the Capsalidae and its relationships to likely sister groups, many aspects of the classification, systematics and biology of this family are unresolved despite study for nearly 230 years. This paper reviews capsalid history and diversity, provides new phylogenetic hypotheses and discusses current subfamilial composition and classification, highlights a conundrum about the identity of an enigmatic 'species' and concludes by considering what research is needed to clarify our understanding of this cosmopolitan family with broad host associations.

\section{AN OVERVIEW OF THE CAPSAlidae}

Presently, there are about 200 described capsalid species in nine subfamilies (Table 1; Figs. 1-9) and 44-46 genera. The host range comprises elasmobranchs (sharks and batoids; see Whittington and Chisholm 2003) and teleosts, including primitive sturgeons (Yamaguti 1963, Whittington et al. 2004). Because of their direct life cycle, some monogeneans can affect fish in captivity (e.g. Chisholm et al. 2004, this issue) and

This paper was presented at the 6th International Symposium on Fish Parasites in Bloemfontein, South Africa, 22-26 September 2003. 
there are increasing reports that some capsalids adversely affect fish in aquaculture and are even responsible for epizootic events (Whittington et al. 2004).

A search of CAB Abstracts for a 20-year period (CAB Abstracts 1984-October 2003) available electronically lists 136 publications that pertain, in some way, to capsalids. This equates to approximately seven papers per year and mostly includes studies on taxonomy, surveys of fish for parasites, biology and ultrastructure, the health problems caused to hosts and methods to control the pathogens. No Monogenea can be considered 'critical' parasites in the same context as agents that cause malaria $(19,639$ publications in $\mathrm{CAB}$ over the same 20-year span), Cryptosporidium $(5,044)$, Giardia $(4,432)$ and Enterobius $(1,030)$. However, some monogenean groups, e.g. dactylogyrids (468) and gyrodactylids (416), do compare reasonably favourably in terms of publication numbers over the last 20 years with other fish parasites of economic importance such as Myxozoa (1,316), Caligidae (478) and Lepeophtheirus (350). With current expansion worldwide of sea-cage farming of fishes, capsalids are likely to escalate in importance in the future. Nevertheless, there has been a sustained history of capsalid study since the first report of a monogenean from Atlantic halibut, Hippoglossus hippoglossus (Pleuronectidae), by Müller (1776).

To the best of my knowledge, Entobdella hippoglossi, reported by Müller (1776) as a leech (Hirudo hippoglossi) from the skin of Hippoglossus hippoglossus, was not only the first capsalid to be described formally, but was also the first published species description of what we now know as a monogenean. The study by Otto Friedrich Müller (1730-1784) was the first published survey of Danish and Norwegian fauna and he established the classification of several animal groups unknown to Linnaeus (Müller 1776). Indeed, the report of what we now know as E. hippoglossi occurred only 18 years after Linnaeus described the host fish! Müller (1776) predates descriptions of other parasite species by another famous Danish scientist, the veterinarian pioneer, P.C. Abildgaard (1740-1801), who described the second capsalid species, Nitzschia sturionis (again as a leech, Hirudo sturionis) from sturgeon (see Abildgaard 1794).

As well as having the longest history of study among the Monogenea, members of the Capsalidae have other claims to fame. Some are among the largest monogeneans reported (Capsala martinieri at $27 \mathrm{~mm}$ long $\times$ $23 \mathrm{~mm}$ wide, Yamaguti 1963, p. 116; E. hippoglossi up to $24 \mathrm{~mm}$ long $\times$ up to $11 \mathrm{~mm}$ wide, Yamaguti 1963, p. 126; N. sturionis $13-14 \mathrm{~mm}$ long $\times 5-6 \mathrm{~mm}$ wide, Yamaguti 1963, p. 133). Other large capsalids are known to be concealed on their hosts, a phenomenon first reported by van Beneden (1856) for Epibdella (now Benedenia) sciaenae from Sciaena aquila (Sciaenidae) off the Belgian coast. van Beneden (1856) described ruby-coloured pigmentation dorsally throughout the body and haptor of B. sciaenae and later commented that the pigment bestowed apparent camouflage to the parasite because he had to focus carefully to locate the beasts (van Beneden 1858). While much remains to be determined about most of the Capsalidae, it is paradoxical that one capsalid species is probably the most intensively studied and well known of all monogenean parasites. Meticulous study and experimental research by Graham Kearn (e.g. see references in Whittington 1994 and Kearn 1998) has provided a detailed picture of the life of Entobdella soleae from the skin of common sole, Solea solea (Soleidae) in Europe. Indeed, we may know more about the biology of E. soleae than any other parasitic flatworm (e.g. respiration; feeding and excretion; attachment by the haptor and by anterior glands; locomotion, migration and dispersal; nuances of the life cycle; egg manufacture, structure, laying and hatching; larval anatomy and behaviour; host-finding and host-specificity; invasion, migration, development and longevity; sense organs; mating, sperm, insemination and fertilisation). In the last 20 years, 18 of 136 publications on capsalids (13\%) from CAB Abstracts are Kearn's detailed studies on E. soleae. It is pleasing that E. soleae is presented as a typical monogenean species in parasitology textbooks (e.g. Roberts and Janovy 2000) next to atypical Monogenea such as gyrodactylids, known for their viviparity, and the polystomatids, which typically infect internal sites of frogs and turtles. If E. soleae is a famous capsalid, then Neobenedenia melleni is infamous as a widespread pathogen of many teleost species in aquaria and aquaculture (e.g. see Deveney et al. 2001). Most Monogenea are legendary for their strict host-specificity (e.g. see Whittington et al. 2000), but $N$. melleni is renowned for the broadest host-specificity of any monogenean species, recorded from $>100$ species in $>30$ families from five orders of captive and wild teleosts (Lawler 1981, Whittington and Horton 1996, Bullard et al. 2000b). Another capsalid, Benedenia seriolae, has been a longstanding pathogen of Seriola species (Carangidae) in intensive culture in Japan (Whittington et al. 2001b). Approximately $20 \%$ of the total production costs for farmed Seriola species in Japan (industry value: $\sim$ US\$1.2 billion; Ernst et al. 2002) is spent to control $B$. seriolae. Cultivation of Seriola species in sea-cages is expanding globally and B. seriolae may occur anywhere these carangid species are found (Whittington et al. 2001b). Benedenia seriolae, therefore, is likely the most costly monogenean species worldwide in terms of stock value.

Some members of the Capsalidae have several claims to fame within the Monogenea: the first; among the biggest; camouflage to conceal them; the best-studied exemplar species; largest host range; most costly in finfish aquaculture. The family also enjoys one of the longest generic names courtesy of Yamaguti (1966): Lagenivaginopseudobenedenia! 


\section{DIVERSITY}

Host diversity. Many more capsalid species await discovery and description and it is possible that unusual capsalid-host associations will be uncovered. Presently, marine teleosts are by far the most common hosts, accounting reliably for all but five capsalid genera and 188 species (see footnotes 4 and 6 in Table 1 for Dioncus and Sprostonia, respectively). The anadromous acipenserids (sturgeons) host only the Nitzschiinae (two Nitzschia species). Fifteen species in five genera are reliably reported to parasitize elasmobranchs (see footnotes 4 and 6 in Table 1). Although most capsalids infect teleosts, the fact that family members parasitize ancient (sharks, rays and sturgeons) and modern (teleost) fishes demands that a complete knowledge and understanding of capsalids is critical for a full comprehension of long-standing questions about early evolution and radiation of Monogenea across fishes. Boeger and Kritsky (1997) proposed that capsalids coevolved with their principally modern fish hosts and dispersed secondarily, by host-switching, to older lineages, but until recently no phylogenetic hypothesis for the Capsalidae has been available to test this suggestion (see below). Entobdella is exclusive because six species infect ray skin and three species parasitize the skin of some flatfish teleost species (Whittington et al. 2004), but E. hippoglossi has been recorded from a roundbodied teleost species (Egorova 2000a, Table 1).

Conservative body and haptor, but diverse microhabitats. Morphology of the Capsalidae at the subfamilial level is illustrated in Figs. 1-9. Most capsalids, except the Encotyllabinae (Fig. 4), have a flattened, leaf-like body. The encotyllabines, however, are simply a variation on the capsalid ground plan because the body edges are folded ventrally, the resulting tube-like body terminating posteriorly in a bell-shaped haptor at the end of a muscular, sometimes very long, peduncle. The different subfamilies can be characterised generally by different combinations of haptor morphology (whether septate or aseptate) and testis number (Figs. 19 and below).

Table 1. Current capsalid subfamilies and included genera (listed alphabetically).

\begin{tabular}{|c|c|}
\hline $\begin{array}{l}\text { Subfamilies } \\
\text { (No. of genera in bold) }\end{array}$ & $\begin{array}{c}\text { Included genera } \\
\text { (Approx. no. of species in parentheses; genera in bold denotes those with species } \\
\text { that parasitize elasmobranchs) }\end{array}$ \\
\hline Benedeniinae Johnston, 1931 (14) & $\begin{array}{l}\text { Allobenedenia (2), Allometabenedeniella (1), Ancyrocotyle (2), **Benedenia } \\
\text { (21), Benedeniella (2), Calicobenedenia (1), Dioncopseudobenedenia (1), } \\
\text { Lagenivaginopseudobenedenia (2), Menziesia (5), Metabenedeniella (2), } \\
\text { Neobenedenia (6), Oligoncobenedenia (1), Pseudallobenedenia (2), } \\
\text { Trimusculotrema (4) }\end{array}$ \\
\hline${ }^{*}$ Capsalinae Baird, $1853(5 \text { or } 7)^{1}$ & $\begin{array}{l}\text { Caballerocotyla }(24), * * \text { Capsala }(14,3,+1)^{2}, \text { Capsaloides }(10), \text { Nasicola (2), } \\
\text { Tricotyla }(0,3)^{3} \text { Tristoma }(8) \text { Tristomella }(0,8)^{3}\end{array}$ \\
\hline Dioncinae Johnston et Tiegs, 1922 (1) & **Dioncus ${ }^{4}(11)$ \\
\hline Encotyllabinae Monticelli, 1892 (2) & Alloencotyllabe (1), **Encotyllabe (17) \\
\hline Entobdellinae Bychowsky, 1957 (2) & ${ }^{* *}$ Entobdella $(9)^{5}$, Pseudoentobdella $(1)$ \\
\hline $\begin{array}{l}\text { Interniloculinae } \\
\quad \text { Suriano et Beverley-Burton, } 1979 \text { (1) }\end{array}$ & **Interniloculus (2) \\
\hline Nitzschiinae Johnston, 1931 (1) & **Nitzschia $(2)$ \\
\hline Pseudonitzschiinae Yamaguti, 1965 (1) & **Pseudonitzschia $(1)$ \\
\hline $\begin{array}{l}\text { Trochopodinae (Price, 1936) } \\
\quad \text { Sproston, } 1946(\mathbf{1 7})\end{array}$ & $\begin{array}{l}\text { Allomegalocotyla (2), Macrophyllida (1), Mediavagina (2), Megalobenedenia } \\
\text { (2), Megalocotyle (6), Megalocotyloides (6), Pseudobenedenia (3), } \\
\text { Pseudobenedeniella (1), Pseudobenedenoides (2), Pseudomegalocotyla (1), } \\
\text { Sessilorbis (1), Sprostonia }(2 ?)^{6}, \text { Sprostoniella (3), Tetrasepta (1), Trilobiodiscus } \\
\text { (1), Trochopella (1), **Trochopus (15) }\end{array}$ \\
\hline
\end{tabular}

* indicates subfamily contains type species (Capsala martinieri) for the Capsalidae;

** indicates type genus for each subfamily;

${ }^{1}$ difference in genera is due to different opinions about capsaline composition between Egorova (1989) and Lamothe-Argumedo (1997);

${ }^{2}$ Egorova (1989) considered Capsala to contain 14 species but Lamothe-Argumedo (1997) lists only three species, assigning others to

Tricotyla and Tristomella. Kardousha (2002) described a new species (C. naffari);

${ }^{3}$ difference in species number is due to different opinions between Egorova (1989) and Lamothe-Argumedo (1997) about generic

composition of capsalines. In each case, the first number follows Egorova, the second follows Lamothe-Argumedo;

${ }^{4}$ while Dioncus postoncomiracidia are reported from skin of blacktip sharks (Carcharhinus limbatus) (Carcharhinidae), adult specimens of Dioncus occur on teleosts of the families Carangidae, Echeneidae and Rachycentridae (see Bullard et al. 2000a);

${ }^{5}$ of the nine described Entobdella species, six parasitize batoids and three parasitize flatfish teleosts (but see Egorova 2000a);

${ }^{6}$ host associations in Sprostonia require re-evaluation because according to Egorova (1994a), the host of the type species, S. squatinae, is the angel shark Squatina squatina (Squatinidae) but the host of Sprostonia longiphallus is the teleost, Epinephelus tauvina (Serranidae). Table compiled from Dyer and Poly (2002), Egorova (1989, 1994a, b, 1997, 1999, 2000a, b, c, d), Klassen et al. (1989), Kritsky and Fennessy (1999), Lamothe-Argumedo (1997), Oliva and Luque (1995), Pérez Ponce de León and Mendoza-Garfías (2000), Timofeeva et al. (1987), Timofeeva (1995), Wheeler and Beverley-Burton (1987), Whittington and Barton (1990), Whittington and Horton (1996), Whittington et al. (2001a) and Yamaguti $(1963,1965,1966,1968)$. 
Except for the encotyllabines (Fig. 4), the capsalid haptor is also remarkably conservative. The basic arrangement comprises a saucer-shaped attachment organ armed with three pairs of median sclerites that are usually large, 14 small hooklets at the periphery of the haptor proper and a thin, membranous marginal valve around the edge (Fig. 10). Median sclerites comprise acentral pair of accessory sclerites (according to Kearn 1963, derived from continual growth of centrally located hooklets of pair I) and two pairs of ventrally directed hamuli (an anterior and a posterior pair; Fig. 10). There is evidence from some species that median sclerites and hooklets do effect mechanical attachment of the parasite to host tissue, but in other species, the capacity of the capsalid haptor to generate suction has contributed appreciably to their expansion across a wide range of host surfaces (Kearn 1994). The arrangement of musculature external to the haptor, tendons entering the haptor from these extrinsic muscles and the way these elements interact play a major role in how the haptor generates suction. In some species (e.g. E. soleae; see Kearn 1994), muscles within the haptor cup itself may also be capable of generating suction independent of other mechanisms. In other species, partitions (loculi) have evolved on the ventral haptor surface formed by divisions (septa; Figs. 2-4, 6, 9). Each loculus can provide suction (Kearn 1994), an innovation also present in monocotylids (e.g. Chisholm and Whittington 1998). For many capsalids and monocotylids, the presence of a marginal valve is critical to maintaining suction. There is unsubstantiated evidence that Trimusculotrema species, which lack a marginal valve and also lack large median sclerites in the haptor, may use an adhesive to attach to host ray skin (Kearn 1994).

Despite the relatively conservative capsalid haptor, species can attach securely to many different tissues as demonstrated by the diversity of microhabitats parasitized. Sites include the epithelium-covered lamina of teleost scales (e.g. E. soleae, see Kearn 1964), the smooth ventral epithelium of batoids (e.g. E. australis, see Kearn 1978), gill lamellae, gill arches and gill rakers of teleosts (e.g. Benedenia and Trochopus, see Whittington and Kearn 1991) and elasmobranchs, individual fins and the branchiostegal membranes of teleosts (e.g. Benedenia lutjani, see Whittington and Kearn 1993, Whittington and Ernst 2002) and deep folds around the lips of teleosts (Whittington, unpublished observation). The bell-shaped haptor of Encotyllabe species is well suited for attachment to the soft, plentiful epithelium around the pharyngeal tooth pads of teleosts (e.g. Kearn and Whittington 1992, Whittington and Kearn 1992). The basic, cup-like suctorial haptor of adult capsalids is unlikely, however, to effect secure attachment to rough surfaces such as the fine, closely spaced denticles of shark skin. To my knowledge, there are no reliable reports of adult capsalids that attach to denticles. Bullard et al. (2000a) reported postlarvae of a Dioncus sp. (as Dionchus sp.) from shark skin providing support for the hypothesis that dioncine oncomiracidia may use the phoretic 'sponsor fish' to which their own 'suckerfish' teleost hosts attach (see footnote 4 in Table 1) as a platform to disperse to other 'suckerfish' individuals. However, the case for postlarval dioncines on shark skin is special. Should the hypothesis of Boeger and Kritsky (2001) that some microbothriids are capsalids be supported by future studies, this will emphasise the need for a reappraisal of haptor structure and diversity among the resultant broader, familial assemblage.

\section{PHENETICS, CURRENT SUBFAMILIES AND NEW PHYLOGENETIC HYPOTHESES FOR THE CAPSALIDAE}

The current classification for the Capsalidae is phenetic. Therefore, it can be argued that all taxa, whether species, genera, subfamilies and indeed the family, are arbitrary constructs based on subjective opinions. Knowledge of capsalid diversity, morphology and biology has progressed, but a good understanding of homology is lacking and it is in this area of assessing structures and elucidating homologies where extra research must be directed. However, the current composition of the Capsalidae finally provides a single unique morphological character that unites the family.

A synapomorphy for the Capsalidae? Addition of Dioncus and Dioncinae to the Capsalidae by Timofeeva (1990), based on haptoral and reproductive morphology, went largely unnoticed, but further support was provided from sperm morphology (Justine et al. 1985, 1991, Justine and Mattei 1987, Justine 1991) and other reproductive studies (Timofeeva 1988). The close relationship between 'dioncids' and capsalids was also noted by Boeger and Kritsky (2001). By including the Dioncinae in the Capsalidae, a single character (accessory sclerites on the haptor) supports the family (Whittington et al. 2004). This is a significant advance for the unity of the Capsalidae because previously, it has been difficult to identify a morphological feature that is unambiguously homologous across species in the family. To the best of my knowledge, accessory sclerites are absent in only two capsalid species, namely Pseudonitzschia uku (Pseudonitzschiinae) and Calicobenedenia polyprioni (Benedeniinae), but these are likely to be secondary losses. A study of the larvae of each of these species can test this hypothesis and I predict that accessory sclerites will be present.

Current subfamilial characters and composition. Recent significant advances have extended Yamaguti's (1963) 'traditional' capsalid classification of five subfamilies (Benedeniinae, Capsalinae, Encotyllabinae, Nitzschiinae, Trochopodinae) to include the Dioncinae, Entobdellinae, Interniloculinae and Pseudonitzschiinae. For a historical account and relevant literature concerning decisions on which current capsalid classification is 


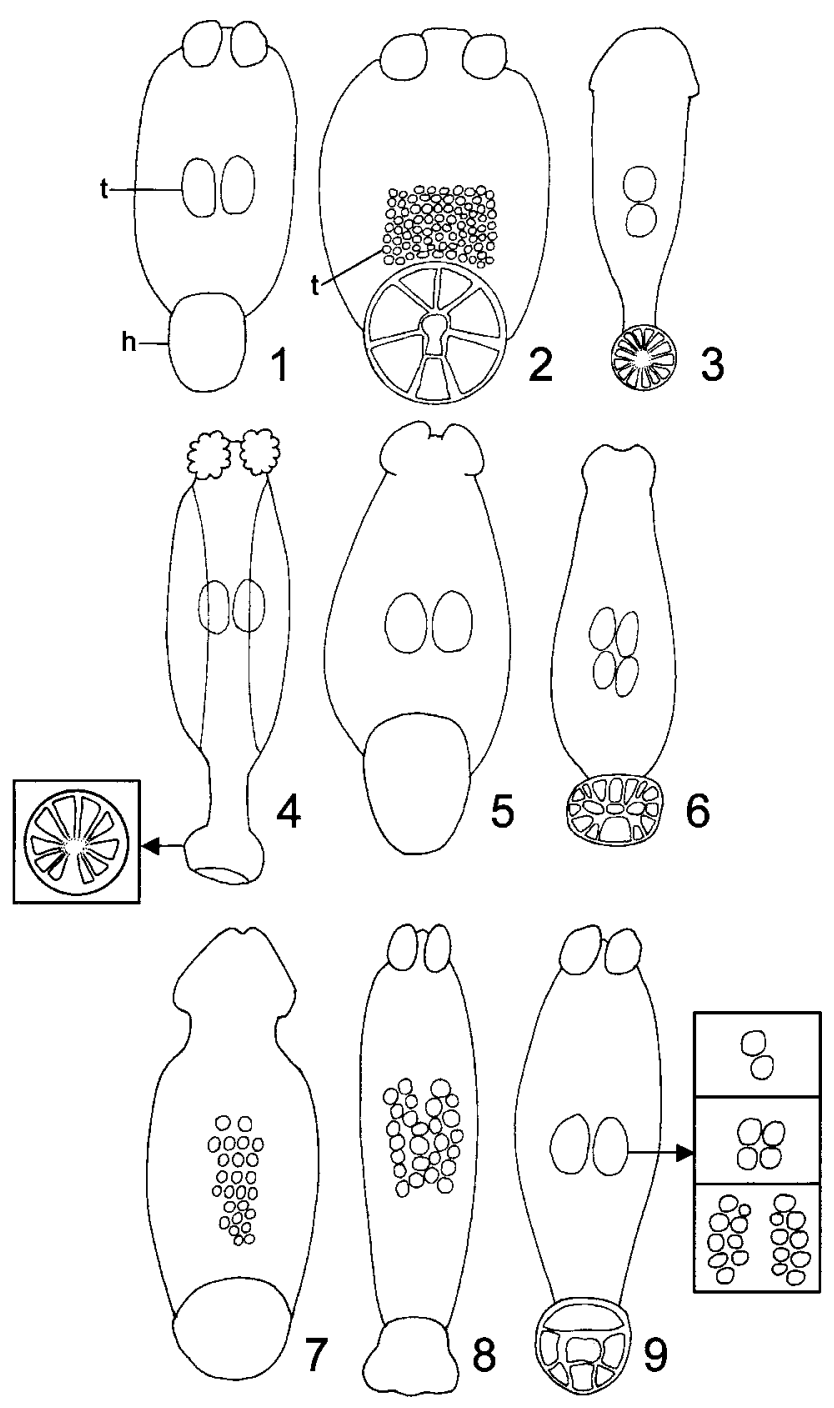

Figs. 1-9. Diagrammatic illustrations (not to scale) of the nine subfamilies comprising the Capsalidae Baird, 1853 in alphabetical order. Haptor (h) morphology (aseptate or septate) and number (two, four or multiple) and arrangement of testes ( $t$ ) are major characters that distinguish subfamilies. Haptoral sclerites and marginal valve are not depicted (but see Fig. 10). Fig. 1. Benedeniinae. Fig. 2. Capsalinae. Fig. 3. Dioncinae. Fig. 4. Encotyllabinae. Fig. 5. Entobdellinae. Fig. 6. Interniloculinae. Fig. 7. Nitzschiinae. Fig. 8. Pseudonitzschiinae. Fig. 9. Trochopodinae. Boxed insets for Figs. 4 and 9 clarify status for haptor and testes arrangement, respectively.

based (Table 1), consult Whittington et al. (2004). Four subfamilies have an aseptate haptor (Benedeniinae Fig. 1, Entobdellinae-Fig. 5, Nitzschiinae-Fig. 7, Pseudonitzschiinae-Fig. 8). Five subfamilies possess a pair of testes arranged either side by side (juxtaposed; Benedeniinae-Fig. 1, Encotyllabinae-Fig. 4, Entobdellinae-Fig. 5, most Trochopodinae-Fig. 9) or one behind the other (in tandem; Dioncinae-Fig. 3; a few Trochopodinae-Fig. 9 inset). Members of the remaining subfamilies have four (Interniloculinae-Fig. 6; a few Trochopodinae-Fig. 9 inset) or multiple testes (Capsa-
linae-Fig. 2, Nitzschiinae-Fig. 7, PseudonitzschiinaeFig. 8, a few Trochopodinae-Fig. 9 inset). When used in combination, haptor morphology and number and arrangement of testes mostly define each subfamily. However, high-level capsalid classification has long been contentious (e.g. Klassen et al. 1989, Kritsky and Fennessy 1999, Whittington et al. 2001a, Whittington et al. 2004).

Several rigorous taxonomic treatments and morphological studies have provided major advances to establish the validity, composition and unification of some subfamilies (e.g. for Benedeniinae, see Whittington and Horton 1996, Egorova 1997, Whittington et al. 2001a; for Capsalinae, see Egorova 1989, 2000b, LamotheArgumedo 1997; for Dioncinae, see Timofeeva 1990, Egorova 2000c; for Encotyllabinae, see Egorova 2000d; for Entobdellinae, see Egorova 1999). Poor diagnoses and the small size of other subfamilies (Interniloculinae, Pseudonitzschiinae; Table 1) indicate that additional study may resolve their validity and composition, but I predict further investigation will place both interniloculine species (Interniloculus chilensis, I. sebastidis) and the only pseudonitzschiine species (Pseudonitzschia $u k u)$ in the Trochopodinae. Although there are only two valid species of Nitzschia ( $N$. sturionis, N. superba), their unique morphology and host association (parasites of acipenserids) appears to justify the validity of the Nitzschiinae.

Subfamilies requiring further study. The validity of genera and species in the Capsalinae and Trochopodinae are now most in need of extensive reappraisal. These two large subfamilies each comprise approximately 50 species and together account for $>50 \%$ of all described capsalid taxa. Egorova (1989) and LamotheArgumedo (1997) disagree about the number of capsaline genera which impacts on the composition of other genera (see footnotes $1-3$ in Table 1). The Trochopodinae, almost exclusively parasites from gills of perciform teleosts, are perhaps the most morphologically diverse subfamily with regard to: number of haptoral loculi; arrangement of anterior attachment apparatus; number of testes (two arranged either juxtaposed [e.g. Megalocotyloides] or in tandem [e.g. Macrophyllida], four [e.g. Trilobiodiscus] or multiple in two groups [e.g. Sprostoniella]) (see Egorova 1994a) (Fig. 9 and insets). The large number of genera containing few species reflects morphological diversity in trochopodines: all but three of the 17 genera contain only one to three species (Table 1).

Phylogenetic hypotheses. A major obstacle for all previous capsalid classification schemes has been that no comprehensive phylogeny has been proposed for the family. Some have questioned whether it is a monophyletic group (Kritsky and Fennessy 1999). Mollaret et al. (2000) used large subunit ribosomal DNA (lsrDNA) sequence data to try to resolve high-level relationships in the Monogenea and in doing so, their study provided 


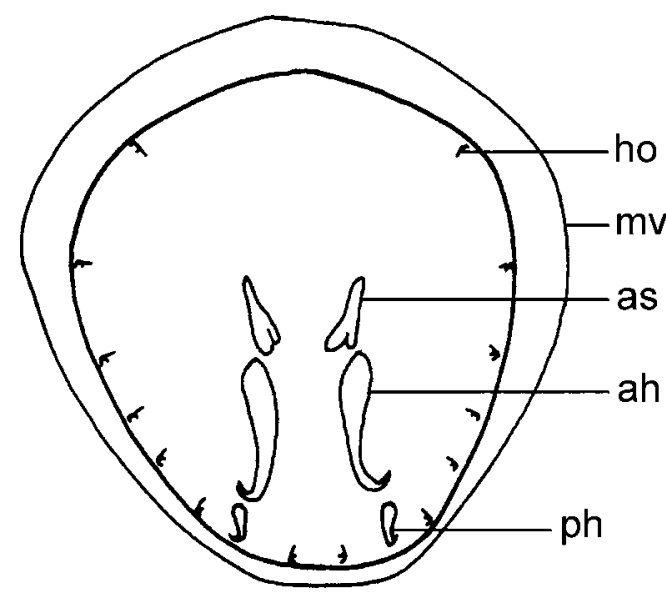

Fig. 10. Diagrammatic representation of typical capsalid haptor showing accessory sclerites (as), anterior hamuli (ah), posterior hamuli (ph), hooklets (ho) and marginal valve (mv).

foundation for some capsalid interrelationships. Using data from only six species, they demonstrated that the Capsalidae was monophyletic and that there was support for capsalines (Capsala onchidiocotyle, Tristoma integrum), encotyllabines (Encotyllabe caballeroi) and trochopodines (Trochopus pini). Apparently unacquainted with taxonomic revisions based on morphology by Egorova (1999) and her recognition of the Entobdellinae, Mollaret et al. (2000) considered that their data showed the Benedeniinae to be paraphyletic because Entobdella australis and Benedenia lutjani (both thought to be benedeniines) fell in separate clades. Their results, however, actually provided support for Egorova's (1999) hypothesis.

Recently, using lsrDNA sequence data, Whittington et al. (2004) extended the number of capsalid taxa studied by Mollaret et al. (2000) to 17 species representing seven genera and five subfamilies and provided two trees based on analyses of different sequence lengths. Fig. 11 shows a generic level phylogeny based on sequence data from 14 species in five genera analysed by Whittington et al. (2004). This preliminary phylogeny provides good branch support for the monophyly of the Capsalinae, Encotyllabinae and Entobdellinae (Fig. 11). However, the Benedeniinae, represented by Neobenedenia and Benedenia (Fig. 11), is again paraphyletic (see Whittington et al. 2004), but for a different reason from the analysis by Mollaret et al. (2000).

Phenetics versus phylogeny. Phylogenetic analyses of trochopodine species, using morphological and molecular characters, will be beneficial to assess relationships within and between subfamilies. Use of loculi in phylogenetic studies should, however, be viewed with caution. It is thought the evolution of haptoral septa and loculi has arisen independently in capsalids and monocotylids. The preliminary phylogenetic hypothesis proposed for capsalids by Whit- tington et al. (2004) suggests that perhaps haptoral septa may also have evolved independently twice within the Capsalidae because benedeniines (aseptate haptor, Fig. 1 ), encotyllabines and trochopodines (septate haptor, Figs. 4-inset and 9, respectively) cluster together in the expanded data set of Whittington et al. (2004; see their fig. 1) whereas capsalines (septate haptor, Fig. 2) and entobdellines (aseptate haptor, Fig. 5) form a separate clade (e.g. Fig. 11). However, polarity of loculi and septa as characters are presently unclear. An alternative scenario is that septa and loculi are plesiomorphic for the Capsalidae and should this be the case, then their loss giving rise to an aseptate haptor may have occurred independently at least twice in capsalid evolution. Further study may resolve this puzzle and will be helped by identifying appropriate monogenean sister groups to the Capsalidae. Morphological analysis indicates that the closest sister groups are the Monocotylidae and Loimoidae (see Boeger and Kritsky 2001), but molecular studies infer that Udonellidae and Gyrodactylidea are closest (Olson and Littlewood 2002). Furthermore, if some microbothriids are in fact capsalids (Boeger and Kritsky 2001), then it is critical to determine the relative placement of the Microbothriidae to all these taxa.

How many capsalid subfamilies should there be? Some key capsalid taxa were not included (e.g. no representatives from Dioncinae or Nitzschiinae) by Whittington et al. (2004), but their preliminary analysis does provide a framework on which to build. Several issues arise from their study (Fig. 11) and deserve a brief mention. The Capsalidae presently comprises nine subfamilies (Table 1; Figs. 1-9), but is this number appropriate? For example, how can the issue of paraphyly in the Benedeniinae from Whittington et al. (2004) be resolved (see also Fig. 11)? Monophyly can be achieved by reassigning all Benedeniinae to the Encotyllabinae (this subfamily has priority, see Table 1). Because of the bellshaped haptor of the Encotyllabinae (Fig. 4 inset), a clear view of its ventral surface is difficult, but morphological studies indicate some larval and juvenile encotyllabines have a septate haptor (e.g. Whittington and Kearn 1992), providing strong support for a separate subfamily from the Benedeniinae (where septa are unknown in larvae, juveniles and adults). A thorough morphological reappraisal of encotyllabines is needed because there are hints of subtle differences in the female reproductive system (e.g. presence of a short, vaginal 'pouch'). This is probably best achieved by studies of live specimens because the reproductive systems of many capsalids often cannot be resolved clearly from preserved material. Whittington et al. (2004) provided strong bootstrap support for a clade containing Neobenedenia based on molecular data (e.g. Fig. 11) and this could be interpreted as excellent evidence for the proposal of a new subfamily, Neobenedeniinae. This potential new subfamily also has strong morphological support (e.g. absence of a vagina; presence of two 


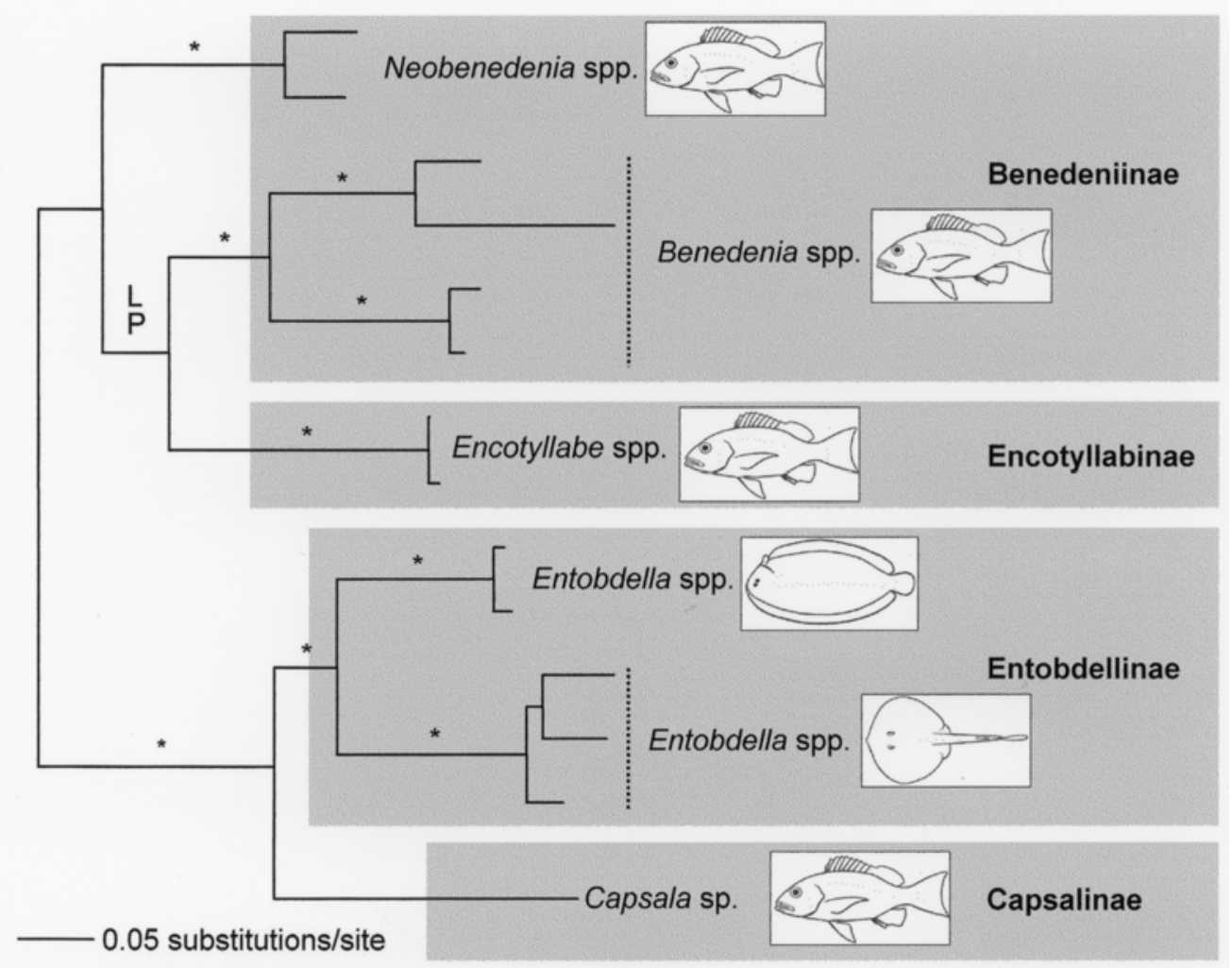

Fig. 11. Maximum likelihood tree for five capsalid genera inferred from lsrDNA sequences of 14 species (based on Data Set B of 693 characters in Whittington et al. 2004). * indicates $\geq 70 \%$ support for all tree generation methods used (maximum likelihood (L), distance (D) and parsimony analysis (P); for details see Whittington et al. 2004). L and P indicates $\geq 70 \%$ support for these analyses. Shaded blocks indicate current subfamilial designations and fish icons indicate host associations for capsalid species studied (i.e. round-bodied or flatfish teleosts and dasyatid elasmobranchs).

sphincters in the female reproductive system; Whittington and Horton 1996). However, it is too early to make this decision for several reasons: currently, Neobenedenia comprises only six species (but see below); some existing species require re-evaluation (e.g. N. longiprostata and $N$. pacifica; work in progress with Emma Fajer-Avila, Roxana Bertha Inohuye-Rivera and Juan Carlos Pérez-Urbiola in Mexico); there are issues about possible cryptic species in the genus (see below).

The Entobdellinae: a pivotal subfamily. The preliminary molecular phylogeny for the Capsalidae of Whittington et al. (2004) (see also Fig. 11) provides further, strong support for the Entobdellinae (see also Egorova 1999, Mollaret et al. 2000) and confirms that Bychowsky's (1957) reasons for separating Entobdellalike monogeneans from Benedenia-like monogeneans were sound. The exclusiveness of Entobdella was highlighted earlier: it is the only capsalid genus that contains species that infect rays (E. apiocolpos, $E$. australis, E. bumpusii, E. corona, E. diadema, E. guberleti) and teleosts (E. hippoglossi, E. pugetensis, E. soleae) (see footnote 5 in Table 1). These distinct host associations are strongly reflected in the study of Whittington et al. (2004) where two Entobdella species from teleosts fall in a separate clade from three Entobdella species from batoids (see also Fig. 11). This analysis indicates that a reappraisal of Entobdella is required and this approach is already being taken. Two previously described Entobdella species from rays are being moved to a new genus together with two new entobdellines from rays off North America (personal communication, Ash Bullard, Gulf Coast Research Laboratory, Mississippi, USA). Two new Entobdella species from batoids in Australia (Entobdella species 1 and 2 of Whittington et al. 2004) are also being described (Kearn and Whittington, in preparation). Furthermore, there are strong morphological grounds to unite two genera currently in the Benedeniinae and which infect the skin of rays with the rest of the Entobdellinae (Whittington, in preparation). In doing so, the Entobdellinae will comprise species in genera that mostly infect the skin and gills of batoids, with the exception of the type genus Entobdella, three species of which infect teleosts (Table 1).

Fig. 11 indicates that the sister group to the entobdellines is the Capsalinae, represented in the analysis by Capsala martinieri from the teleost, the ocean sunfish, Mola mola (Molidae) (see Whittington et al. 2004). 
This preliminary phylogeny, therefore, appears to support the coevolutionary hypothesis proposed by Boeger and Kritsky (1997) and suggests that entobdellines may represent a relatively recent capsalid radiation derived from capsalines (or capsaline-like ancestors) on teleosts. If my new conception of the Entobdellinae (see above) is correct, the fact that most described and newly discovered entobdellines infect batoids implies that teleosts may be a newly acquired host group for this subfamily. Should this hypothesis be correct, then species currently in Entobdella that mostly infect bottom-dwelling teleost flatfishes (Table 1) may be the result of ecological transfer(s) from bottom-dwelling rays onto bony fish, as suggested by Llewellyn (1982). The alternative scenario, however, that entobdellines may have transferred from flatfish teleosts onto batoids living in the same environment also cannot be discounted. The report of E. hippoglossi from a roundbodied teleost, Sebastes glaucus (Scorpaenidae), rather than the usual array of pleuronectid and soleid flatfishes (Egorova 2000a) suggests that infection of teleosts by entobdellines may be more widespread than previously thought. However, this record by Egorova (2000a) is based on only a single specimen recovered from gills of the scorpaenid and awaits verification. Future parasitehost surveys and taxonomic studies of capsalid diversity should shed more light on associations. Lawler (1981) provides a useful and detailed list of parasite-host associations, including capsalids, covering literature up to 1968.

\section{IDENTITY ISSUES: THE ENIGMATIC CAPSALID, NEOBENEDENIA MELLENI}

A capsalid species reported from spadefish (Ephippidae) and angelfish (Pomacanthidae) in the New York Aquarium by MacCallum (1927) was named in honour of Miss Ida Mellen, who first noticed the outbreak, as Epibdella (now Neobenedenia) melleni. Ida Mellen, a zoologist of note herself, probably had no inkling that her namesake monogenean would become a parasite of such notoriety! Outbreaks of $N$. melleni continued on teleosts in the New York Aquarium and Jahn and Kuhn (1932) reported it from $>50$ species in nearly 20 families in three orders. Reports of the host range of $N$. melleni at the New York Aquarium continued (Nigrelli and Breder 1934, Nigrelli 1935, 1937, $1940,1943,1947)$ and even in the 1990s, outbreaks alleged to be $N$. melleni still occurred on captive teleosts (personal communications, Denis Thoney and Alistair Dove). For full accounts of the host range of N. melleni, consult Lawler (1981), Whittington and Horton (1996) and Bullard et al. (2000b). In revising the generic diagnosis for Neobenedenia, Whittington and Horton (1996) noted the considerable variety of forms among $>80$ specimens attributed to $N$. melleni from various host species.
The most significant issue in attempting to resolve the taxonomy of $N$. melleni is determining the host species on which the pathogen was first introduced into the New York Aquarium. No type host species was designated by MacCallum (1927). Whittington and Horton (1996, p. 1119) highlighted the confusion over whether $N$. melleni established with a shipment of bandtail puffer, Sphoeroides spengerli (Tetraodontidae), from the western Atlantic Ocean or on bullseye puffer, S. annulatus (Tetraodontidae), from the eastern Pacific Ocean. Jahn and Kuhn (1932) were of the opinion that $N$. melleni infections were initiated in the New York Aquarium with a shipment of fish from the West Indies. This disarray is exacerbated further because MacCallum (1927) pooled adult specimens of $N$. melleni from different host fish species on the same microscope slides making it impossible to resolve the question: what is $N$. melleni? Unfortunately, subsequent outbreaks and reports of a capsalid species identified as $N$. melleni on teleosts from many localities worldwide have not been accompanied by voucher specimens lodged in museums for verification (Whittington and Horton 1996, p. 1126), except for the studies by Kaneko et al. (1988), Bullard et al. (2000b) and Deveney et al. (2001).

The geographic distribution of $N$. melleni reported from wild hosts (Whittington and Horton 1996, Bullard et al. 2000b) is focused around North America along the Pacific coast, Caribbean Sea and Gulf of Mexico region of the western Atlantic Ocean. Reports of N. melleni from teleosts in mariculture may involve its transfer from wild to farmed host species (e.g. Kaneko et al. 1988), but this requires substantiation. If outbreaks of $N$. melleni in aquaculture are included, its distribution extends west across the Pacific Ocean to Hawaii (Kaneko et al. 1988), Japan (as $N$. girellae, synonymised with $N$. melleni by Whittington and Horton 1996), an aquaculture station in Bali (Koesharyani et al. 1999) and the east coast of Australia (Deveney et al. 2001). Neobenedenia melleni is also reported from a cichlid, a coryphaenid and a sparid in the Red Sea in culture facilities of the National Center for Mariculture in Eilat, Israel (Colorni 1994). There are also records of a Neobenedenia sp. from various host species cultured in floating sea-cages off Malaysia (Leong 1997).

The first and, so far, only report of a capsalid identified as $N$. melleni from Australia is symptomatic of the progressive mystery that surrounds this species. In August 2000, it appeared on barramundi, Lates calcarifer (Centropomidae), in sea-cages off north Queensland and 200,000 fish were killed in three weeks, but the origin of the outbreak remains unknown (Deveney et al. 2001). Presumably, the parasite lives naturally on a local teleost species near this barramundi farm and 'switched' to the larger biomass of cultured fish when sea temperatures dropped and perhaps depressed the immunological defences of $L$. calcarifer (see Deveney et al. 2001). However, the identity of a likely 'natural' 
host species in Australia is unknown. So far, no repeat outbreaks have occurred in Australian waters.

Incidents above summarise major impediments when defining the taxon ' $N$. melleni'. Whittington and Horton (1996) synonymised $N$. girellae with $N$. melleni, a decision not accepted universally (e.g. Ogawa and Yokoyama 1998, Koesharyani et al. 1999), but in doing so, alternative actions were explored. The broad hostspecificity reported for $N$. melleni is especially atypical for Monogenea and prompted Whittington and Horton (1996, p. 1133) to consider whether in fact the taxon they identified as $N$. 'melleni' may be a complex of two or more morphologically indistinguishable species. There is recent genetic evidence that this situation is now very likely (Whittington et al. 2004). Two 'isolates' (one from a population on Sphoeroides annulatus (Tetraodontidae) from the Sea of Cortez, Mexico; another from a population on Oreochromis sp. (Cichlidae) in culture facilities in the Red Sea, Israel), each identified by me on morphological grounds as $N$. melleni, differed genetically by $9.52 \%$ over nearly 700 sites of lsrDNA sequence (Whittington et al. 2004; see also Neobenedenia clade in Fig. 11). It appears that these two N. 'melleni' isolates are different species, although verification using different genetic markers will be valuable. Investigations in progress on morphology, site-specificity and biology (Whittington with colleagues Emma Fajer-Avila, Roxana Bertha InohuyeRivera and Juan Carlos Pérez-Urbiola in Mexico) further substantiate the species complex hypothesis. I predict further study will reveal several, close Neobenedenia relatives throughout the range currently attributed to $N$. 'melleni' that warrant separate species status.

If $N$. 'melleni' is a species complex, it explains some of the aberrant aspects of its biology such as its catholic host-specificity, extensive morphological variation and wide geographic distribution. I suspect that the capsalid problem attributed to the $N$. melleni of MacCallum (1927) in the New York Aquarium has, in reality, been a continual introduction of specimens of the $N$. 'melleni' complex on many different teleost species from many different regions! The species complex hypothesis may also explain the sudden appearance of $N$. 'melleni' on fish in sea-cages off Hawaii and Queensland, Australia and perhaps elsewhere, too. This scenario may support the likelihood that several $N$. 'melleni'-like species live naturally on, but cause no problems to, wild teleost species throughout the geographic range presently credited to $N$. 'melleni'. For reasons currently unknown, some of these species may have an opportunity or the capacity to switch to new teleost species in culture nearby. If $N$. 'melleni' is a suite of species, it also raises many new questions. For example: How many species are there? How can we discriminate them morphologically? How are they distributed geographically? (i.e. Do they have a restricted distribution or are they more widespread?). Are they usually host-specific? Do they display site-specificity and infect particular fins (e.g. Whittington and Kearn 1993) and/or other sites? Is there significant variation in their biology (e.g. fecundity, generation time, method and impact of feeding and attachment)? If so, do these differences contribute to significant differences in pathogenicity between species? How many pathogenic species are there?

Further morphological and molecular analyses of $N$. 'melleni' isolates are needed. In association with these studies, molecular data from Neobenedenia species that are clearly distinguishable morphologically (e.g. $N$. longiprostata, $N$. pacifica) are also required and these studies are underway (Whittington with colleagues Emma Fajer-Avila, Roxana Bertha Inohuye-Rivera and Juan Carlos Pérez-Urbiola in Mexico). Undoubtedly $N$. 'melleni' is set to remain an enigmatic capsalid in the future until some of these issues are resolved.

\section{INFORMATION REQUIRED TO IMPROVE KNOWLEDGE OF CAPSALIDS}

Here, I summarise some potential avenues for future studies in areas of: site- and host-diversity (both intimately linked to phylogeny and radiation); morphology and structure (and their strong foundation for systematics and phylogeny); potential species complexes (with implications for identification, host-specificity, pathogenicity, fish health and shipment of fish stocks).

Diversity of sites and hosts. Future surveys of marine fishes will divulge new capsalid species. Sites under-explored for capsalids include individual fins (Timofeeva et al. 1987, Whittington and Kearn 1993), buccal cavity (Garcia et al. 2000, Al-Mathal 2002, Kardousha 2002), branchiostegal membranes (Whittington and Ernst 2002) and nares (Wheeler and Beverley-Burton 1987) of bony fishes. This range of unusual and cryptic sites coupled with transparency and/or pigmentation (Whittington 1996) has undoubtedly concealed many species from eager fish parasitologists. The extensive microhabitat range of capsalids on teleosts demonstrates continual diversification. Discovery of several, live encotyllabines at different distances along the oesophagus of some bony fishes (Whittington, unpublished report) suggests further adaptive radiation into new sites. Surveys of nasal tissue and the buccal cavity of elasmobranch hosts are worthwhile to determine whether the family has diversified beyond the skin and gills of this lineage.

At least two teleost families host an interesting diversity of capsalids. Species in the Lutjanidae are parasitized by species of Pseudonitzschia (Pseudonitzschiinae) (see Yamaguti 1965), Benedenia (e.g. see Whittington and Kearn 1993), Lagenivaginopseudobenedenia, Pseudallobenedenia (see Timofeeva 1995), Neobenedenia (Benedeniinae) (see Bullard et al. 2000b) and Trilobiodiscus (Trochopodinae) (see Egorova 1994a). Species of the Scorpaenidae can host species of 
the following trochopodine genera: Megalobenedenia, Megalocotyle, Megalocotyloides and Trochopus (see Egorova 1994a). Lutjanids and scorpaenids would seem, therefore, especially fruitful host groups on which to focus to reveal more about capsalid diversity, but other bony fish families should not be ignored and elasmobranchs also present worthy hosts for study (see below).

Phylogeny. To understand early evolution and expansion of Monogenea across fish, an understanding of the associations between capsalids and their modern and ancient host lineages is critical. To achieve this, a comprehensive phylogeny for the Capsalidae and their hosts is key, but information on the host diversity parasitized by specific subfamilies, and perhaps particular genera, will be instructive. I argued above that elasmobranchs may be a recently acquired host lineage and this is supported by a provisional capsalid phylogeny (e.g. Fig. 11) and by the fact that few species (15 of $\sim 200$ species or $7.5 \%$ ) parasitize rays and sharks. Whittington and Chisholm (2003) stated that chondrichthyans were probably under-represented as hosts for Monogenea because few shark and ray species globally have been studied specifically for them. The Entobdellinae seems a crucial subfamily to study for an appreciation of capsalid monogeneans and their broad relationship with fishes because all but three species parasitize elasmobranchs. Future sampling may indicate whether Entobdella species are more widespread across teleosts and if so, whether this includes more round-bodied species (e.g. Egorova 2000a). Further analysis of phylogeny must also include the few representatives of the Trochopodinae reported from elasmobranchs (Table 1). The indications are that capsalids may have radiated onto the Chondrichthyes at least twice unless relationships between entobdellines and trochopodines are closer than is currently perceived.

Opportunities for radiation. The report by Bullard et al. (2000a) of Dioncus sp. postlarvae on shark skin provides insight into a mechanism that may have allowed capsalids to 'backtrack' evolutionarily from modern teleosts to older elasmobranchs. Hosts of Dioncus species include 'suckerfish' (Echeneis, Rachycentron, Remora, see footnote 4 in Table 1) that hitch a ride on larger, sponsor organisms such as large teleosts, sharks, rays, turtles and cetaceans (Froese and Pauly 2003). The phoretic association between 'suckerfish' and large teleosts, sharks and rays may have provided a means for capsalids to spread from modern to older fish groups (and perhaps vice versa) in addition to ecological transfer between bottom-dwelling batoids and teleosts proposed by Llewellyn (1982). Future phylogenetic analyses including dioncine, entobdelline and trochopodine species may shed more light on this hypothesis.

Morphology and structure. Lack of knowledge about homologous characters has been a major hindrance to a command of capsalid phylogeny. Haptoral septa and loculi, considered of significance in mono- genean systematics by some authors (e.g. for capsalids, see Yamaguti 1963; for monocotylids, see Chisholm et al. 1995), may, in fact, be unuseful characters for the Capsalidae because septa may have arisen more than once. Furthermore, haptoral septa in capsalids can be overlooked (e.g. Gibson 1976, Egorova 1994b), especially if specimens are heavily compressed. The glands of Goto are usually tiny, paired glands normally found in the posterior angle between the testes. They can be exceedingly difficult to see in live adults (Whittington and Horton 1996) and are sometimes reported as absent (e.g. Ogawa et al. 1995a, Timofeeva 1995). Glands of Goto may be present in some larval capsalids (e.g. Kearn 1963, Whittington and Kearn 1992, 1993, Whittington et al. 1994) and Whittington and Kearn (1992) recognised them in a juvenile specimen of Encotyllabe caballeroi (Encotyllabinae). Larval studies, therefore, will be profitable in future analyses of the ubiquity or otherwise of these mysterious organs. To the best of my knowledge, glands of Goto are not reported in other monogenean families. Their small size in most adult capsalids precludes their use as a second unique morphological synapomorphy for the family, but further critical study may necessitate a reappraisal.

Larval morphology and structure may also prove informative for capsalid systematics. I predicted earlier that studies of oncomiracidia of those capsalid species that, when adult, are reported to lack accessory sclerites, will likely reveal their presence. I also believe that careful study of the tendon path associated with the accessory sclerites in larval capsalids (e.g. Whittington and Kearn 1992) will be key to supporting current phylogenetic hypotheses for the family. Furthermore, detailed examination of the ciliated cells that bear locomotory cilia and study of the chaetotaxy (sensory sensilla) of capsalid larvae and comparisons between species representing currently recognised subfamilies may shed light on phylogenetic associations. Ciliated cells and chaetotaxy of larvae can be visualised using silver staining (e.g. Chisholm 1998) and scanning electron microscopy (e.g. Cribb et al. 2003) and these studies have proved useful in systematic research (e.g. Justine et al. 1985, Gusev and Timofeeva 1986, Chisholm 1998). Examinations of ciliated cells and chaetotaxy seem likely to be valuable additions to capsalid research.

'Male copulatory organ' is often used generically for a sclerotised male intromittent organ (e.g. for dactylogyrids, diplectanids, microbothriids and monocotylids). To my knowledge, Allometabenedeniella orbicularicola is the only capsalid with an entirely sclerotised 'male copulatory organ' (e.g. see Velasquez 1982). All other described capsalids have a penis (a muscular, protrusible organ as in Benedenia species, see Whittington et al. 2001a) or a cirrus (an eversible organ that turns inside out during eversion, as in many cestodes, and as reported for Trimusculotrema uarnaki, see Whittington and Barton 1990). Capsalid reproduction deserves more 
study, but in particular, the morphology, structure and any functional advantages between a penis and cirrus, perhaps in relation to site-specificity and the habits and habitats of host species, merit scrutiny. When anatomy and functional morphology of male genitalia in capsalids are better understood, this may have systematic and phylogenetic significance.

Species complexes? In addition to Neobenedenia 'melleni', other capsalid species also exhibit broad hostspecificity (e.g. Benedenia hawaiiensis, see Yamaguti 1968; B. epinepheli, see Ogawa et al. 1995b; Pseudobenedenia nototheniae and Pseudobenedenoides shorti, see Garcia et al. 2000). Whittington et al. (2001a) noted that B. epinepheli and B. hawaiiensis are morphologically similar and it is worth considering whether these capsalids with low host-specificity may also represent a complex of several, similar species. A study of 23 species of notothenioid fishes from the Atlantic region of Antarctica and Subantarctica by Timofeeva et al. (1987) revealed four similar capsalid species (Pseudobenedenia nototheniae and three new species, P. gibberifrons, $P$. dissostichii and Pseudobenedeniella branchialis), each with different site and host preferences. These examples indicate that species complexes among the Capsalidae may not be uncommon.

Assessments of differences in host- and site-specificity between individuals sharing similar morphology may prove to be important biological attributes for separating monogenean species in a complex. Other than possible differences in 'habitat preference', it is also essential to assess differences in biology (e.g. fecundity, generation time and feeding) because these may have implications for pathogenicity. For example, should $N$. 'melleni' prove to be a complex of many species across a broad geographic area, the repercussions for fish health and disease management are serious. There are reports that pathogenic capsalids have been introduced into new areas when fish stocks cross international borders (e.g. $N$. girellae may have been imported to Japan with amberjack fry from Hong Kong and Hainan, China; Ogawa et al. 1995a). If there is a large complex of Neobenedenia species (the N. 'melleni' complex?), introductions to new areas may be less of a concern and more manageable than a scenario of several endemic populations of $N$. 'melleni'-like capsalids local to specific regions, but which are currently unidentified on their natural host species and which may pose threats to cultured stocks nearby. This is likely what happened in outbreaks of $N$. 'melleni' in Hawaii and Australia (see Kaneko et al. 1988 and Deveney et al. 2001, respectively). To identify likely endemic $N$. 'melleni'-like parasites that we never knew existed, surveys are critical for fish health, aquaculture, quarantine and the import and export of fishes.
A way forward. To address the multitude of questions raised, a holistic approach is required combining studies on systematics, larval and adult structure with new emphases on the examination of live material, molecular analyses and investigations on the diversity of host species and sites parasitized. Significant advances will arise from the collection and study of live, freshly collected parasite material from fresh, appropriately identified host fishes. In these investigations, it is vital to ensure that there is a useful trail of high quality parasite (e.g. mounted types; mounted and unmounted voucher specimens) and host (e.g. a type or voucher specimen) material lodged in recognised, curated museum collections that are accessible to future scientists to continue their studies. Current developments in molecular genetic analyses demand that a proportion of parasite and host material should be lodged in institutions able to store material preserved in high-grade ethanol or, as a superior alternative, as frozen specimens to facilitate molecular studies by others later.

Acknowledgements. I thank the many colleagues, collaborators and students who have helped with my ongoing studies on capsalid monogeneans over the years: Rob Adlard, Julian Baggio, Di Barton, Mary Beverley-Burton, Clinton Chambers, Leslie Chisholm, Peter Cook, Serge Corneillie, Bronwen Cribb, Marty Deveney, Ingo Ernst, Emma Fajer-Avila, Adam Fletcher, Rod Garner, Bronwyn Gillanders, María del Carmen Gómez del Prado Rosas, Lexa Grutter, Judy Halliday, Tamarind Hamwood, Marnie Horton, Graham Kearn, Joep Kleine Staarman, Jess Morgan, Robin Overstreet, Priya Pitt, Roxana Bertha Inohuye-Rivera, Klaus Rohde, Clive Talbot, Juan Carlos Pérez-Urbiola, Drew Veary and Susan Wyborn. Although I have never met T.P. Egorova (Vladivostok, Russia), I admire her studies of capsalids and thank her for her enormous contributions to their systematics, which have helped my own thoughts and ideas. I appreciate the support of The University of Queensland (1987-2001), its research facilities (notably the Centre for Microscopy and Microanalysis, Heron Island Research Station and Moreton Bay Research Station), The South Australian Museum, Adelaide, The University of Adelaide and Lizard Island Research Station where different portions of my capsalid studies have been made. I am grateful to the Australian Academy of Science, the Australian Research Council, the New South Wales Game Fishing Association, the University of Queensland and Yamaha Nutreco Aquatech, Japan for financial support. Leslie Chisholm (University of Adelaide) provided valuable critiques on earlier versions of this contribution. I thank Ash Bullard (Gulf Coast Research Laboratory, University of Southern Mississippi, USA) for access to a pre-submission copy of his manuscript on entobdellines from batoids off North America. I am grateful to the organisers of the Sixth International Symposium on Fish Parasites (held in Bloemfontein, South Africa, 22-26 September 2003), especially Jo Van As and Linda Basson, for the invitation to present this work at the symposium and for the opportunity to submit this synthesis for publication in this issue. 


\section{REFERENCES}

ABILDGAARD P.C. 1794: Beskrivelse af en nye Snylte-Orm, funden paa Horn-Fiskens Gieller (Axine belones). Skr. Naturh.-Selsk., Kiøbenhavn. 3: 59-60.

AL-MATHAL E.M. 2002: Identification of some monogenetic trematodes from some Arabian Gulf fish in Saudi Arabia. J. Egypt. Soc. Parasitol. 32: 959-967.

BOEGER W.A., KRITSKY D.C. 1997: Coevolution of the Monogenoidea (Platyhelminthes) based on a revised hypothesis of parasite phylogeny. Int. J. Parasitol. 27: 14951511.

BOEGER W.A., KRITSKY D.C. 2001: Phylogenetic relationships of the Monogenoidea. In: D.T.J. Littlewood and R.A. Bray (Eds.), Interrelationships of the Platyhelminthes. Taylor and Francis, London and New York, pp. 92102.

BULLARD S.A., BENZ G.W., BRASWELL J.S. 2000a: Dionchus postoncomiracidia (Monogenea: Dionchidae) from the skin of blacktip sharks, Carcharhinus limbatus (Carcharhinidae). J. Parasitol. 86: 245-250.

BULLARD S.A., BENZ G.W., OVERSTREET R.M., WILLIAMS E.H. Jr., HEMDAL J. 2000b: Six new host records and an updated list of wild hosts for Neobenedenia melleni (MacCallum) (Monogenea: Capsalidae). Comp. Parasitol. 67: 190-196.

BYCHOWSKY B.E. 1957: Monogenetic Trematodes, their Systematics and Phylogeny. Izdatel'stvo Akademii Nauk SSSR, Moscow. (In Russian: English translation edited by Hargis, W.J. Jr., 1961), 627 pp.

CAB ABSTRACTS: Electronic resource of the Commonwealth Agricultural Bureau International (CABI) in association with SilverPlatter International, CABI, St Albans.

CHISHOLM L.A. 1998: Ciliated cells and chaetotaxy of the larvae of seven species of monocotylid monogeneans (Platyhelminthes) from Heron Island, Great Barrier Reef, Australia. Parasitol. Res. 84: 828-834.

CHISHOLM L.A., WHEELER T.A., BEVERLEY-BURTON M. 1995: A phylogenetic analysis and revised classification of the Monocotylidae Taschenberg, 1879 (Monogenea). Syst. Parasitol. 32: 159-191.

CHISHOLM L.A., WHITTINGTON I.D. 1998: Morphology and development of the haptors among the Monocotylidae (Monogenea). Hydrobiologia 383: 251-261.

CHISHOLM L.A., WHITTINGTON I.D., FISCHER A.B.P. 2004: A review of Dendromonocotyle (Monogenea: Monocotylidae) from the skin of stingrays and their control in public aquaria. Folia Parasitol. 51: 123-130.

COLORNI A. 1994: Hyperparasitism of Amyloodinium ocellatum (Dinoflagellida: Oodinidae) on Neobenedenia melleni (Monogenea: Capsalidae). Dis. Aquat. Org. 19: $157-159$

CRIBB B.W., CHISHOLM L.A., GOULD R., WHITTINGTON I.D. 2003: Morphology, ultrastructure and implied function of ciliated sensory structures on the developmental stages of Merizocotyle icopae (Monogenea: Monocotylidae). Microsc. Res. Techniq. 62: 267-276.

DEVENEY M.R., CHISHOLM L.A., WHITTINGTON I.D. 2001: First published record of the pathogenic mono- genean parasite Neobenedenia melleni (Capsalidae) from Australia. Dis. Aquat. Org. 46: 79-82.

DYER W.G., POLY W.J. 2002: Trimusculotrema schwartzi n. sp. (Monogenea: Capsalidae) from the skin of the stingray Dasyatis zugei (Elasmobranchii: Dasyatidae) off Hong Kong, China. Syst. Parasitol. 51: 217-225.

EGOROVA T.P. 1989: A taxonomic analysis of the subfamily Capsalinae (Monogenoidea; Capsalidae). In: B.I. Lebedev (Ed.), Parazitologicheskie issledovaniya: sbornik nauchnykh trudov. Dal'nevostochnoe otdelenie. Akademiya Nauk SSSR, Vladivostok, pp. 46-54. (In Russian.)

EGOROVA T.P. 1994a: A taxonomic review of the subfamily Trochopodinae (Monogenoidea: Capsalidae). Parazitologiya 28: 81-91. (In Russian.)

EGOROVA T.P. 1994b: About a new genus, Megalobenedenia (Capsalidae: Trochopodinae). Parazitologiya 28: 76-78. (In Russian.)

EGOROVA T.P. 1997: A taxonomic review of the subfamily Benedeniinae (Monogenoidea: Capsalidae). Parazitologiya 31: 438-451. (In Russian.)

EGOROVA T.P. 1999: Systematics of the subfamily Entobdellinae (Monogenoidea: Capsalidae). Parazitologiya 33: 420-425. (In Russian.)

EGOROVA T.P. 2000a: Entobdella hippoglossi (Monogenoidea, Capsalidae) from a perch-like fish from the Pacific Ocean and new data on Sessilorbis limopharynx. Parazitologiya 34: 70-74. (In Russian.)

EGOROVA T.P. 2000b: Occurrence of monogeneans of the subfamily Capsalinae (Capsalidae) - parasites of marine fishes. Parazitologiya 34: 111-117. (In Russian.)

EGOROVA T.P. 2000c: New monogeneans of the genus Dionchus (Capsalidae: Dionchinae). Parazitologiya 34: 252-258. (In Russian.)

EGOROVA T.P. 2000d: Recent composition of the subfamily Encotyllabinae (Monogenea: Capsalidae). Parazitologiya 34: 295-301. (In Russian.)

ERNST I., WHITTINGTON I., CORNEILLIE S., TALBOT C. 2002: Monogenean parasites in sea-cage aquaculture. Austasia Aquacult. February/March 2002: 46-48.

FROESE R., PAULY D. (Eds.) 2003: FishBase. World Wide Web electronic publication, www.fishbase.org, 06 December 2003.

GARCIA R.G.G.F., PRADI-GARCIA M.M., del VALLE M.T., RODRIGUEZ-DIEGO J.G. 2000: Nuevas especies de hospederos y localización para Pseudobenedenia nototheniae y Pseudobenedenoides shorti (Monogenea: Capsalidae) en peces antárticos. Rev. Salud Anim. 22: 61-63.

GIBSON D.I. 1976: Monogenea and Digenea from fishes. Discovery Rep. 36: 179-266.

GUSEV A.V., TIMOFEEVA T.A. 1986: The ciliary cells and chaetotaxy of the larvae of Nitzschia sturionis (Abildgaard, 1794). (Monogenea, Capsalidae). Tr. Zool. Inst. 155: 55-61. (In Russian.)

JAHN T.L., KUHN L.R. 1932: The life history of Epibdella melleni MacCallum, 1927, a monogenetic trematode parasitic on marine fishes. Biol. Bull. 62: 89-111.

JUSTINE J.-L. 1991: Cladistic study in the Monogenea (Platyhelminthes), based upon a parsimony analysis of 
spermiogenetic and spermatozoal ultrastructural characters. Int. J. Parasitol. 21: 821-838.

JUSTINE J.-L., LAMBERT A., MATTEI X. 1985: Spermatazoon ultrastructure and phylogenetic relationships in the monogeneans (Platyhelminthes). Int. J. Parasitol. 15: 601608.

JUSTINE J.-L., MATTEI X. 1987: Phylogenetic relationships between the families Capsalidae and Dionchidae (Platyhelminthes, Monogenea, Monopisthocotylea) indicated by the comparative ultrastructural study of spermiogenesis. Zool. Scr. 16: 111-116.

JUSTINE J.-L., MATTEI X., EUZET L. 1991: Ultrastructure of spermatozoa in two monopisthocotylean monogeneans: Encotyllabe sp. (Capsalidae) and Tetraonchoides sp. (Tetraonchoididae). Ann. Parasitol. Hum. Comp. 66: 173178.

KANEKO J.J., YAMADA R., BROCK J.A., NAKAMURA R.M. 1988: Infection of tilapia, Oreochromis mossambicus (Trewavas), by a marine monogenean, Neobenedenia melleni (MacCallum, 1927) Yamaguti, 1963 in Kaneohe Bay, Hawaii, USA, and its treatment. J. Fish Dis. 11: 295300.

KARDOUSHA M.M. 2002: Monogenea of Arabian Gulf fishes. 1. Descriptions of three Capsala spp. (Capsalidae) including Capsala naffari n. sp. infecting mackerel tuna Euthynnus affinis from coasts of Emirates. Parasitol. Int. 51: 327-335.

KEARN G.C. 1963: The egg, oncomiracidium and larval development of Entobdella soleae, a monogenean skin parasite of the common sole. Parasitology 53: 435-447.

KEARN G.C. 1964: The attachment of the monogenean Entobdella soleae to the skin of the common sole. Parasitology 54: 327-335.

KEARN G.C. 1978: Entobdella australis, sp. nov., a skinparasitic monogenean from the Queensland stingrays Taeniura lymma and Amphotistius kuhlii. Aust. J. Zool. 26: 207-214.

KEARN G.C. 1994: Evolutionary expansion of the Monogenea. Int. J. Parasitol. 24: 1227-1271.

KEARN G.C. 1998: Parasitism and the Platyhelminths. Chapman and Hall, London, 544 pp.

KEARN G.C., WHITTINGTON I.D. 1992: A response to light in an adult encotyllabine (capsalid) monogenean from the pharyngeal tooth pads of some marine teleost fishes. Int. J. Parasitol. 22: 119-121.

KLASSEN G.J., BEVERLEY-BURTON M., LOCKE A. 1989: A revision of Entobdella Blainville (Monogenea: Capsalidae) with particular reference to E. hippoglossi and E. squamula: the use of ratios in taxonomy and key to species. Can. J. Zool. 67: 1869-1876.

KOESHARYANI I., ZAFRAN, YUASA Y., HATAI K. 1999: Two species of capsalid monogeneans infecting cultured humpback grouper Cromileptes altivelis in Indonesia. Fish Pathol. 34: 165-166.

KRITSKY D.C., FENNESSY C.J. 1999: Calicobenedenia polyprioni n. gen., n. sp. (Monogenoidea: Capsalidae) from the external surfaces of wreckfish, Polyprion americanus (Teleostei: Polyprionidae), in the North Atlantic. J. Parasitol. 85: 192-195.
LAMOTHE-ARGUMEDO R. 1997: Nuevo arreglo taxonómico de la subfamilia Capsalinae (Monogenea: Capsalinae), clave para los géneros y dos combinaciones nuevas. An. Inst. Biol. Univ. Nac. Autón. Mex. (Zool.) 68: $207-$ 223.

LAWLER A.R. 1981: Zoogeography and host-specificity of the superfamily Capsaloidea Price, 1936 (Monogenea: Monopisthocotylea). An evaluation of the host-parasite locality records of the superfamily Capsaloidea Price, 1936, and their utility in determinations of host-specificity and zoogeography. Special Papers in Marine Science No. 6, 650 pp. Gloucester Point, Virginia, USA: Virginia Institute of Marine Science and School of Marine Science, College of William and Mary.

LEONG T.S. 1997: Control of parasites in cultured marine finfishes in southeast Asia - an overview. Int. J. Parasitol. 27: 1177-1184.

LLEWELLYN J. 1982: Host-specificity and corresponding evolution in monogenean flatworms and vertebrates. Mém. Mus. Natl. Hist. Nat. Paris, Nouv. Sér., Sér. A (Zool.) 123: 289-293.

MacCALLUM G.A. 1927: A new ectoparasitic trematode, Epibdella melleni, sp. nov. Zoopathology 1: 291-300.

MOLLARET I., JAMIESON B.G.M., JUSTINE J.-L. 2000: Phylogeny of the Monopisthocotylea and Polyopisthocotylea (Platyhelminthes) inferred from 28S rDNA sequences. Int. J. Parasitol. 30: 171-185.

MÜLLER O.F. 1776: Zoologiae Danicae Prodromus, Seu Animalium Daniae et Norvegiae Indigernarum Characteres, Nomina, et Synonyma Imprimis Popularium. Havniae, $282 \mathrm{pp}$.

NIGRELLI R.F. 1935: Studies on the acquired immunity of the pompano, Trachinotus carolinus, to Epibdella melleni. J. Parasitol. 21: 438-439.

NIGRELLI R.F. 1937: Further studies on the susceptibility and acquired immunity of marine fishes to Epibdella melleni, a monogenetic trematode. Zoologica, N.Y. 22: 185-192.

NIGRELLI R.F. 1940: Mortality statistics for specimens in the New York Aquarium, 1939. Zoologica, N.Y. 25: 525-552.

NIGRELLI R.F. 1943: Causes of diseases and death of fishes in captivity. Zoologica, N.Y. 28: 203-216.

NIGRELLI R.F. 1947: Susceptibility and immunity of marine fishes to Benedenia (= Epibdella) melleni (MacCallum), a monogenetic trematode. III. Natural hosts in the West Indies. J. Parasitol. 33: 25.

NIGRELLI R.F., BREDER C.M. 1934: The susceptibility and immunity of certain marine fishes to Epibdella melleni, a monogenetic trematode. J. Parasitol. 20: 259-269.

OGAWA K., BONDAD-REANTASO M., FUKUDOME M., WAKABAYASHI H. 1995a: Neobenedenia girellae (Hargis, 1955) Yamaguti, 1963 (Monogenea: Capsalidae) from cultured marine fishes of Japan. J. Parasitol. 81: 223-227.

OGAWA K., BONDAD-REANTASO M.G., WAKABAYASHI H. 1995b: Redescription of Benedenia epinepheli (Yamaguti, 1937) Meserve, 1938 (Monogenea: Capsalidae) from cultured and aquarium marine fishes of Japan. Can. J. Fish. Aquat. Sci. 52: 62-70.

OGAWA K., YOKOYAMA H. 1998: Parasitic diseases of cultured marine fish in Japan. Fish Pathol. 33: 303-309. 
OLIVA M.E., LUQUE J.L. 1995: Monogeneans parasitic on marine fishes from Peru and Chile: three new species and two new combinations. Mem. Inst. Oswaldo Cruz 90: $569-574$.

OLSON P.D., LITTLEWOOD D.T.J. 2002: Phylogenetics of the Monogenea - evidence from a medley of molecules. Int. J. Parasitol. 32: 233-244.

PÉREZ PONCE de LEÓN G.P., MENDOZA-GARFÍAS B. 2000: A new species of Sprostoniella Bychowsky and Nagibina, 1967 (Monogenea: Capsalidae) from Chaetodipterus zonatus (Osteichthyes: Ephippidae) in Chamela Bay, Mexico. J. Parasitol. 86: 811-814.

ROBERTS L.S., JANOVY J. Jr. 2000: Gerald D. Schmidt \& Larry S. Roberts' Foundations of Parasitology. Sixth Edition. McGraw-Hill International Editions, Boston, 670 pp.

TIMOFEEVA T.A. 1988: Structure of the genital system of the monogenean genus Dionchus (Monogenea, Dionchidae). Tr. Zool. Inst. 177: 26-34. (In Russian.)

TIMOFEEVA T.A. 1990: Phylogenetic relationships of capsalids and dionchids and the position of the latter in the system of monogeneans (Monogenea, Monopisthocotylea). Tr. Zool. Inst. 221: 3-16. (In Russian.)

TIMOFEEVA T.A. 1995: New species of the genera Pseudallobenedenia Yamaguti, 1966 and Lagenivaginopseudobenedenia Yamaguti, 1966 (Monogenea: Capsalidae) in the Indo-Pacific. Syst. Parasitol. 32: 71-77.

TIMOFEEVA T.A., GAEVSKAYA A.V., KOVALEVA A.A. 1987: Capsalids (Monogenea) of the notothenioid fishes from the Atlantic region of Antarctica and Subantarctica. Tr. Zool. Inst. 161: 78-93. (In Russian.)

van BENEDEN P.J. 1856: Note sur un trematode nouveau de maigre d'Europe. Bull. Acad. R. Belg., Classes Sci. 23: 502-508.

van BENEDEN P.J. 1858: Mémoire sur les Vers Intestinaux. J.-B. Bailtière et Fils, Paris, 376 pp.

VELASQUEZ C.C. 1982: Monogenea (Capsalidae) from Philippine marine fishes. Proc. Helminthol. Soc. Wash. 49: 176-184.

WHEELER T.A., BEVERLEY-BURTON M. 1987: Nasicola hogansi n. sp. (Monogenea: Capsalidae) from bluefin tuna, Thunnus thynnus (Osteichthyes: Scombridae), in the northwest Atlantic. Can. J. Zool. 65: 1947-1950.

WHITTINGTON I.D. 1994: Graham C. Kearn. An appreciation. Int. J. Parasitol. 24: 481-486.

WHITTINGTON I.D. 1996: Benedeniine (capsalid) monogeneans from Australian fishes: pathogenic species, sitespecificity and camouflage. J. Helminthol. 70: 177-184.

WHITTINGTON I.D., BARTON D.P. 1990: A new genus of monogenean parasites (Capsalidae: Benedeniinae) from stingrays (Rajiformes: Dasyatidae) with a description of a new species from the long-tailed stingray Himantura uarnak Forsskål from Queensland, Australia. J. Nat. Hist. 24: $327-340$.

WHITTINGTON I.D., CHISHOLM L.A. 2003: Diversity of Monogenea from Chondrichthyes: do monogeneans fear sharks? In: C. Combes and J. Jourdane (Eds.), Taxonomie, Écologie et Évolution des Métazoaires Parasites. (Livre hommage à Louis Euzet). Tome 2. PUP Perpignan, France, pp. 339-363.

WHITTINGTON I.D., CORNEILLIE S., TALBOT C., MORGAN J.A.T., ADLARD R.D. 2001b: Infections of Seriola quinqueradiata Temminck \& Schlegel and $S$. dumerili (Risso) in Japan by Benedenia seriolae (Monogenea) confirmed by morphology and 28S ribosomal DNA analysis. J. Fish Dis. 24: 421-425.

WHITTINGTON I.D., CRIBB B.W., HAMWOOD T.E., HALLIDAY J.A. 2000: Host-specificity of monogenean (platyhelminth) parasites: a role for anterior adhesive areas? Int. J. Parasitol. 30: 305-320.

WHITTINGTON I.D., DEVENEY M.R., MORGAN J.A.T., CHISHOLM L.A., ADLARD R.D. 2004: A preliminary phylogenetic analysis of the Capsalidae (Platyhelminthes: Monogenea: Monopisthocotylea) inferred from large subunit rDNA sequences. Parasitology 128: 511-519.

WHITTINGTON I.D., DEVENEY M.R., WYBORN S.J. 2001a: A revision of Benedenia Diesing, 1858 including a redescription of B. sciaenae (van Beneden, 1856) Odhner, 1905 and recognition of Menziesia Gibson, 1976 (Monogenea: Capsalidae). J. Nat. Hist. 35: 663-777.

WHITTINGTON I.D., ERNST I. 2002: Migration, site-specificity and development of Benedenia lutjani (Monogenea: Capsalidae) on the surface of its host, Lutjanus carponotatus (Pisces: Lutjanidae). Parasitology 124: 423-434.

WHITTINGTON I.D., HORTON M.A. 1996: A revision of Neobenedenia Yamaguti, 1963 (Monogenea: Capsalidae) including a redescription of $N$. melleni (MacCallum, 1927) Yamaguti, 1963. J. Nat. Hist. 30: 1113-1156.

WHITTINGTON I.D., KEARN G.C. 1991: The adhesive attitudes of some gill-parasitic capsalid monogeneans. J. Helminthol. 65: 280-285.

WHITTINGTON I.D., KEARN G.C. 1992: The eggs and oncomiracidia of Encotyllabe spp. and the relationship between encotyllabines and other capsalid monogeneans. Parasitology 104: 253-261.

WHITTINGTON I.D., KEARN G.C. 1993: A new species of skin-parasitic benedeniine monogenean with a preference for the pelvic fins of its host, Lutjanus carponotatus (Perciformes: Lutjanidae) from the Great Barrier Reef. J. Nat. Hist. 27: 1-14.

WHITTINGTON I.D., KEARN G.C., BEVERLEY-BURTON M. 1994: Benedenia rohdei n. sp. (Monogenea: Capsalidae) from the gills of Lutjanus carponotatus (Perciformes: Lutjanidae) from the Great Barrier Reef, Queensland, Australia, with a description of the oncomiracidium. Syst. Parasitol. 28: 5-13.

YAMAGUTI S. 1963: Systema Helminthum. Volume IV. Monogenea and Aspidocotylea. InterScience Publishers, New York, 699 pp.

YAMAGUTI S. 1965: New monogenetic trematodes from Hawaiian fishes, I. Pac. Sci. 19: 55-95.

YAMAGUTI S. 1966: New monogenetic trematodes from Hawaiian fishes, II. Pac. Sci. 20: 419-434.

YAMAGUTI S. 1968: Monogenetic Trematodes of Hawaiian Fishes. University of Hawaii Press, Honolulu, 287 pp. 